\title{
MILITARY OPERATIONS OF THE POLISH-LITHUANIAN GARRISON IN MOSCOW AGAINST THE FIRST ZEMSTVO MILITIA IN EARLY $1611^{1}$
}

\author{
Vyacheslav N. Kozlyakov \\ Ryazan State University named after S.A. Esenin, Ryazan, Russian Federation
}

\begin{abstract}
Introduction. The article is devoted to the study of the military confrontation between the PolishLithuanian garrison and the Zemstvo forces to counter the organization of the First Zemstvo Militia led by P.P. Lyapunov in early 1611. Methods and materials. Information is analyzed from the previously unknown manuscript of the Diary of the Campaign of King Sigismund III recently introduced into the scientific circulation of materials from the "Russian Archive of Jan Sapieha", the translation of "The Diary of Jan Peter Sapieha", royal messenger Jan Komorowski's report on the uprising in Moscow on March 19, 1611 and the Embassy book on relations between Russia and Poland 1615-1616. Analysis. The ways and goals of the Zemstvo self-organization, begun by Ryazan voyevoda P.P. Lyapunov, are shown and the centers of gathering forces are described. The article reveals the activities of head of the Moscow garrison A. Gosevsky in disrupting the unification movement of the former supporters of Tsar Vasily Shuisky and False Dmitry II, and suppressing the uprising in Moscow to gain a military advantage during the siege of Moscow by militias. Among the measures taken by the Polish-Lithuanian side there was the weakening of the streltsy troops in the Moscow garrison, and the disarmament of the townspeople; an attempt to make a coalition with the impostor hetman Jan Peter Sapega; blocking the main roads along which the militia could move to Moscow. By the order of A. Gosevsky, a campaign was organized for the joint ratification of boyar Prince I.S. Kurakin and the Polish-Lithuanian forces to Vladimir. A well-known role was played by the "Cherkasy" (Cossacks) detachments, who committed a punitive expedition to "Ukrainian cities", which explains the absence of individual military units from this part of the Moscow State in the First Zemstvo Militia. Results. The main military attack was in Moscow on March 19, 1611, which led to the uprising of the inhabitants of Moscow supported by partisans of the First Zemstvo Militia, who at that moment found themselves in Moscow. The consequence of these events was the beginning of the liberation war in Russia.

Key words: First Zemstvo militia, Polish-Lithuanian garrison in Moscow, A. Gosevsky, J.P. Sapega, P.P. Lyapunov, uprising in Moscow on March 19, 1611, negotiations with Polish-Lithuanian ambassadors in 1615.

Citation. Kozlyakov V.N. Military Operations of the Polish-Lithuanian Garrison in Moscow Against the First Zemstvo Militia in Early 1611. Vestnik Volgogradskogo gosudarstvennogo universiteta. Seriya 4. Istoriya. Regionovedenie. Mezhdunarodnye otnosheniya [Science Journal of Volgograd State University. History. Area Studies. International Relations], 2021, vol. 26, no. 1, pp. 23-32. (in Russian). DOI: https://doi.org/10.15688/ jvolsu4.2021.1.3
\end{abstract}

\section{ВОЕННЫЕ ДЕЙСТВИЯ ПОЛЬСКО-ЛИТОВСКОГО ГАРНИЗОНА В МОСКВЕ ПРОТИВ ПЕРВОГО ЗЕМСКОГО ОПОЛЧЕНИЯ В НАЧАЛЕ 1611 ГОДА ${ }^{1}$}

\section{Вячеслав Николаевич Козляков}

\author{
Рязанский государственный университет им. С.А. Есенина, г. Рязань, Российская Федерация
}

Аннотация. Статья посвящена изучению военного противостояния польско-литовского гарнизона с земскими силами для противодействия организации Первого ополчения во главе с П.П. Ляпуновым в начале 1611 года. Анализируются сведения из ранее неизвестной рукописи «Дневник похода короля Сигизмунда III», недавно введенных в научный оборот материалов из «Русского архива Яна Сапеги» и перевода «Дневника 


\section{ВООРУЖЕННЫЕ СИЛЫ И ВОЕННЫЕ ДЕЙСТВИЯ}

Яна Петра Сапеги», реляции королевского гонца Яна Коморовского о восстании в Москве 19 марта 1611 г., посольской книги по связям России и Польши 1615-1616 годов. Показаны пути и цели земской самоорганизации, начатой рязанским воеводой П.П. Ляпуновым, охарактеризованы центры сбора сил. В статье раскрывается деятельность главы московского гарнизона А. Госевского по срыву начавшегося объединительного движения бывших сторонников царя Василия Шуйского и Лжедмитрия II и подавлению восстания в Москве для получения военного преимущества при осаде Москвы силами Первого земского ополчения. Среди предпринимаемых польско-литовской стороной мер было ослабление стрелецких отрядов в составе московского гарнизона и разоружение посадских людей, попытка создания коалиции с гетманом самозванца Яном Петром Сапегой, перекрытие основных дорог, по которым Первое земское ополчение могло двигаться к Москве. По приказу А. Госевского был организован поход совместной рати боярина кн. И.С. Куракина и польско-литовских сил на Владимир. Известную роль сыграли отряды «черкас» - запорожских казаков, совершивших карательный поход в «украинные города», что объясняет отсутствие в Первом ополчении отдельных ратных отрядов из этой части Московского государства. Главный военный удар был нанесен в Москве 19 марта 1611 г., что привело к восстанию жителей московского посада, поддержанному сторонниками Первого земского ополчения, оказавшимися в этот момент в Москве. Следствием этих событий стало начало освободительной войны в России.

Ключевые слова: Первое земское ополчение, польско-литовский гарнизон в Москве, А. Госевский, Я.П. Сапега, П.П. Ляпунов, восстание в Москве 19 марта 1611 г., переговоры с польско-литовскими послами 1615 года.

Цитирование. Козляков В. Н. Военные действия польско-литовского гарнизона в Москве против Первого земского ополчения в начале 1611 года // Вестник Волгоградского государственного университета. Серия 4, История. Регионоведение. Международные отношения. - 2021. - T. 26, № 1. - С. 23-32. - DOI: https:// doi.org/10.15688/jvolsu4.2021.1.3

Введение. История Первого ополчения изучена достаточно подробно в отечественной историографии в работах С.Ф. Платонова, И.С. Шепелева, Н.П. Долинина, А.Л. Станиславского, а в американской историографии - в книге по истории Смуты Ч. Даннинга. 11-12 апреля 2011 г. в Рязани была проведена Всероссийская научная конференция «Смутное время и земские ополчения в начале XVII века. К 400-летию создания Первого ополчения под предводительством П.П. Ляпунова», по ее итогам выпущен сборник трудов, где были подведены итоги изучения темы. Существует проблема исчерпанности русских источников по истории земских ополчений, поэтому одним из перспективных направлений стало исследование польских документов по истории русской Смуты, существенно восполняющих пробелы русских документов (см. работы Б.Н. Флори). В настоящей работе используются введенные в недавнее время в научный оборот коллективом исследователей во главе с И.О. Тюменцевым новые материалы, связанные с архивом Яна Петра Сапеги, реляция королевского гонца Яна Коморовского о восстании в Москве 19 марта 1611 г., опубликованная Т. Бохуном, а также неизвестное продолжение «Дневника королевского похода под Смоленск в 1609-1611 гг.». Целью статьи является изучение военных действий, развернувшихся в столице и разных частях Московского государства, после начала организации Первого земского ополчения во главе с П.П. Ляпуновым в январе 1611 года.

Первые обращения организатора земского ополчения П.П. Ляпунова к боярам в Москву с требованием подтвердить, будут ли исполнены условия избрания королевича Владислава на московский престол, датируются концом декабря 1610 года. Бояре из Москвы написали королю Сигизмунду III под Смоленск, что Прокофий Ляпунов, «со всею Резанью... отложился», и «городы и места заседает», а «денежные доходы и хлеб всякой збирает к себе». Они также упоминали о совместных действиях П.П. Ляпунова с бывшими сторонниками Лжедмитрия II во главе с И.М. Заруцким в Туле [18, № 223, с. 489490; 21, с. 331-332].

Полноценный земский союз стал складываться после начала переговоров П.П. Ляпунова с нижегородским воеводою кн. А.А. Репниным. Грамота из Рязани в Нижний Новгород была перехвачена в Муроме 11 января и отослана в Москву воеводою окольничим кн. В.Ф. Мосальским. Получив сведения о 
грамоте рязанского воеводы, А. Госевский переслал «ядовитый универсал» Ляпунова королю Сигизмунду III под Смоленск. П.П. Ляпунов обращался из Рязани ко всем чинам в Нижнем Новгороде - воеводам и приказным людям, дворянам и детям боярским, стрельцам, казакам, пушкарям и «купцам». С самого начала острие борьбы было направлено против членов Боярской думы, отдавших власть в руки иноземцев и забывших свою «правдивую веру», отступивших от патриарха и других церковных пастырей ради «славы света» и «солодких роскошей». Из Рязани шел призыв: «станем крепко за землю нашу, пойдем против тых, которые пустошат правдивую веру». В грамоте П.П. Ляпунова перечислены основные задачи земского объединения, связанные с общими действиями «всей земли» по организации похода на Москву и выборами царя: «раду зделаем, кому быт на Московском государстве государем» (цит. по: [11, с. 526-527; 21, с. 333-334]). Представители городов, участвовавших в движении, согласно крестоцеловальной записи, обещали «за Московское государьство на полских и литовских людей стояти заодин», «очищати» столицу от врагов [2, № 176, с. 301; № 179, с. 307-308].

Методы. Используются проверенные историографической традицией методы работы с источниками, основанные на принципах историзма. Образно говоря, такой подход можно назвать следованием принципам «школы» Степана Борисовича Веселовского (18761952), внесшего самый большой вклад в изучение истории России XVI-XVII веков. Его труды, основанные на тщательном изучении источников и персоналий, отрицавшие диктатуру методологии классового подхода, лучше всего помогают приблизиться к содержанию исторических событий, не сбиваясь на следование преходящей моде исторических исследований. Привычный метод нарративного описания продолжает служить исторической науке и используется в настоящей работе. С одним важным уточнением об отсутствии у автора позитивистской уверенности, что его реконструкция «как это было на самом деле» является единственно верной. Предлагая свой вариант описания событий, историк может отвечать лишь за создание непротиворечивой картины, отвечающей содержанию историчес- ких источников. В такой парадигме исследования введение в научный оборот новых материалов позволяет уточнять и совершенствовать устоявшуюся историографическую традицию изучения истории русской Смуты начала XVII века.

Анализ. Глава польско-литовского гарнизона в Москве Александр Госевский, получивший к началу 1611 г. боярский чин и стоявший во главе Стрелецкого приказа [14, л. 185 об.], хорошо понимал, чем грозила столице такая земская самоорганизация. «Московский староста» пытался не допустить появления под столицей сил, враждебных королю. Сторонники короля Сигизмунда III контролировали прямую дорогу от Смоленска к Москве - Дорогобуж, Вязьму, Можайск и Волок и старались укрепиться на других путях, откуда могли ожидать прихода собиравшегося П.П. Ляпуновым ополчения. Отчитываясь в письме королю Сигизмунду III 21 января 1611 г., А. Госевский писал о направлении на восставших полка М. Струся, «чтобы перерезать дорогу этому обманщику, которая ведет от Рязани к Москве». Хотя А. Госевскому и приходилось признавать, что силы отряда, посланного против П.П. Ляпунова, были «малы». Призыв идти «на рязанские места» был отправлен также бывшему гетману самозванца Я.П. Сапеге и его войску, квартировавшему в Перемышле, Мещовске и других калужских городах. Однако сапежинцы не откликнулись на просьбы А. Госевского и Боярской думы. Войско Я.П. Сапеги, ранее поддерживавшее Лжедмитрия II, одновременно вело переговоры с московским гарнизоном, королем Сигизмундом III и воеводами в Калуге и Туле об уплате им жалованья за прежние службы. Поэтому сапежинцы не вмешивались в события, выжидая более выгодных условий. Они даже готовы были действовать сообща со сторонниками начинавшегося земского движения, когда писали в Калугу: «а мы свои горла за вас дадим, покаместа вам Бог пошлет государя на Московское государьство» [16, c. 150]. Предложение Я. Сапеги было серьезно воспринято П.П. Ляпуновым, 11 февраля 1611 г. он отослал в Калугу своего племянника Ф.Г. Ляпунова для возможного договора о соединении с сапежинцами, правда, на определенных условиях, поручив этому войску 
быть «в Можайске на дороге»: «а с нами ему в одных полкех не быти» [2, № 182, с. 310312]. В Дневнике Яна Сапеги секретари гетмана записали 14 (24) февраля: «пришли письма из Калуги от Ляпунова и Заруцкого». В тот момент войско гетмана Сапеги обсуждало возможность «идти за леса», но гетман убеждал их еще потерпеть и дождаться результатов своих переговоров с королем Сгизмундом III под Смоленском [7, с. 277-285].

Боярская дума в Москве тоже пыталась противодействовать начинавшемуся земскому движению. Грамота в Тулу, где говорилось о посылке «на Резань... войною пана Сапегу да Струса со многими людми литовскими» не достигла цели, «туленя» отказались поддерживать бояр и переслали их обращение П.П. Ляпунову [2, № 176, с. 301]. В сторону Владимира, через который должно было идти к столице нижегородское ополчение, послали объединенное войско «русских и литовских людей» во главе с боярином кн. И.С. Куракиным. Королевский секретарь Якуб Задзик сообщал в своей переписке: «ротмистр Руцкий с несколькими сотнями кавалерии вышел из столицы и, соединившись с Куракиным, который также имел несколько сотен москвитян, разгромил под Владимиром людей князя Просовецкого (с которыми тот шел к Ляпунову), и почти весь Владимир отложился» [22, с. 278; 9]. Однако отряд кн. И.С. Куракина не смог выполнить своей главной задачи и установить контроль над Владимиром, а казаки атамана А.3. Просовецкого (ошибочно названного в процитированной переписке князем) смогли соединиться с силами ополчения. Отойдя от Владимира в сторону Александровой слободы, рать боярина кн. И.С. Куракина и отряд ротмистра М. Косаковского снова встретили отпор местных жителей, и вынуждены были вернуться в Москву.

Гусарские роты и казачьи полки, подчинявшиеся «пану Руцкому», пытались перекрыть «коломенскую дорогу» «в 10 милях» (примерно, 50 км) от Москвы и даже выбили «неприятеля» из «двух слободок» (возможно, это были сторонники П.П. Ляпунова, отправленные вперед для разведки и подготовки пути к столице от Коломны). Из переписки Рязани и Нижнего Новгорода известно о противодействии сбору ополчения коломенского воево- ды В.Б. Сукина, получившего от короля Коломну «в путь» (кормление) [1, № 176, с. 302; № 179 , с. $306-307 ; 10 ; 24$, p. 360]. По свидетельству Н. Мархоцкого, несколько хоругвей были посланы «на разгром Серпухова» [12, c. 88]. Попытка А. Госевского взять под свой контроль главные дороги, по которым собиралось идти ополчение в Москву, в целом не удалась. Но воеводы в ближайших к Москве городах должны были сделать выбор, поддерживать или нет сбор земских сил. В ополчении, например, не оказалось суздальского воеводы окольничего И.П. Головина, ярославских воевод В.П. Головина и Т.Г. Корсакова, вологодского воеводы Г.Г. Пушкина, не сразу примкнули к движению воеводы в ЮрьевеПольском и Переславле-Залесском [20, с. 322].

Несмотря на противодействие, Первое ополчение сумело объединиться в очень короткое время в январе - феврале 1611 года. Опорой движения стали Переяславль-Рязанский, Тула и Калуга. Говоря об объединении с Тулой и Калугой, воевода П.П. Ляпунов упоминал также союз Рязани «с северскими и украинными городами» [18, № 228, с. 497-498]. Дорога в Северскую землю через Тулу и Орел была перекрыта в начале февраля 1611 г., когда Орел, Кромы, Карачев и Болхов были захвачены и разорены в результате похода запорожских казаков. «Черкасы» расправились с местным населением и отослали воевод под Смоленск к королю Сигизмунду III. Королевский секретарь Якуб Задзик сообщал о действиях казаков, ожидавших дальнейшего приказа от короля: «Великое кровопролитие от такого своеволия, которое весьма отвращает от нас рвение этих людей, тем более, что [казаки] делают сие только ради грабежа и [даже] с теми городами, которые присягали его милости королевичу» $[21$, с. $321,360-361 ; 22$, c. $275-276 ; 24$, р. 361]. Оставался один путь установления союза украинных и северских городов - через Брянск и Калугу. В Брянске находился бывший воевода Лжедмитрия II стольник В.П. Шереметев, там же оказались многие смоленские дворяне и дети боярские, отказавшиеся подчиниться королю Сигизмунду III и потерявшие свои поместья. Разоренные войной служилые люди из Смоленска и «северских городов» собирались в Рославле и Брянске, и вели переписку с главным воево- 
дою осажденного Смоленска боярином М.Б. Шеиным. В апреле - мае 1611 г. Северская земля приняла участие в восстании против короля во главе с И.Н. Салтыковым [21, c. 357-358]. Следовательно, П.П. Ляпунов не случайно упоминал «северские города» как своих союзников, а присоединение Северской земли к земскому движению, действительно, состоялось. Однако дворяне Брянска, Новгород-Северского, Путивля во главе с воеводами В.П. Шереметевым, Ф.П. Барятинским и Ю. Беззубцевым изначально не ставили цели похода на Москву. Они стремились оказать поддержку осажденному королем Сигизмундом III Смоленску, и только неудача восстания привела позже к отъезду ратных людей из «северских городов» в подмосковные полки.

Другими важными центрами сбора Первого ополчения стали города Замосковного края, откуда поддержка земских сил распространилась на Север и в Нижнее Поволжье. Основным центром объединения сил в Замосковном крае стал Нижний Новгород. Обращения из Нижнего Новгорода шли во Владимир, Суздаль, Муром, Кострому, Галич, Ярославль и Вологду. Далее письма переправлялись в Солигалич и Тотьму, Великий Устюг и другие «Поморские городы», достигая Перми и Соликамска. Традиционной была связь Нижнего Новгорода и Ярославля по Волге с Казанью и «Низом». Присоединение к движению по созданию ополчения Ярославля помогло организации союзных действий с Великим Новгородом и близлежащими уездами и городами, включая Тверь, Торжок, Устюжну и Углич [2, № 182, с. 310; № 183, с. 314].

Города от «Немецкой украйны» на северо-западе страны в это время были вовлечены в сложную войну со сторонниками польского короля и нового самозванца Лжедмитрия III, объявившегося в Ивангороде. Вокруг Пскова на стороне короля Сигизмунда III воевал полковник А. Лисовский, поэтому псковичи, ранее поддерживавшие Лжедмитрия II, скорее готовы были принять нового самозванца, чем присоединиться к заключенному в Москве договору о призвании на престол польского королевича. Традиционной была рознь Пскова и Великого Новгорода, где, напротив, присягнули королевичу Владиславу, и куда из Москвы на воеводство был прислан боярин И.М. Сал- тыков [15, с. 144-150]. Новгородцы вели свою войну со шведским войском Я. Делагарди, наступавшим на Корелу и Ладогу. Как писал А. Госевский королю Сигизмунду III, из Москвы, под предлогом помощи Великому Новгороду против шведов, выслали 600 стрельцов и 300 казаков, «к которым было недоверие» [22, с. 208-210]. Однако после получения известий о сборе земского ополчения, в Новгороде Великом произошел переворот против воеводы боярина И.М. Салтыкова, и город вступил в переговоры как с Я. Делагарди, так и с организаторами земского движения [19, с. 347-350].

Сбор земских сил был назначен на Пасху 24 марта 1611 года. За неделю до этого срока, во время празднования Вербного воскресения, в Москве случился очередной конфликт стрельцов, пушкарей и посадских людей с офицерами и солдатами польско-литовского гарнизона, ставший прологом к московской катастрофе 19 марта 1611 года. В составленной «по горячим следам» реляции королевского гонца Яна Коморовского говорилось, что «в Вербное воскресенье, без всякого на то повода, взбунтовавшись, пошло несколько тысяч людей московских, мира и стрельцов в поле». Все это напоминало события, связанные со сведением с престола царя Василия Шуйского, и для такой «демонстрации» необходим был важный предлог, которым стал подход к Москве сил Первого ополчения. Жители Москвы обсуждали «в поле» свои «обиды и притеснения» от солдат польско-литовского гарнизона и требовали защиты, для чего «к Ляпунову за помощью послали» (Ян Коморовский был отослан из-под Смоленска в гонцах 26 марта 1611 г.) [4, с. 294; 17, с. 265]. Только получив уверения А. Госевского в безопасности, москвичи вернулись в город. Но противостояние уже началось, в Москве, как писал Я. Коморовский, появилось 500 стрельцов, высланных вперед воеводами ополчения. В «Страстной вторник», то есть 19 марта, случился конфликт, вызванный отказом посадских людей исполнять приказ А. Госевского о размещении пушек на башнях и воротах Китай-города и Кремля. Тогда, по свидетельству ротмистра Н. Мархоцкого, из Кремля вышли немецкие роты и вместе с польско-литовским «рыцарством» стали расправляться с жите- 


\section{ВООРУЖЕННЫЕ СИЛЫ И ВОЕННЫЕ ДЕЙСТВИЯ}

лями Москвы: «в Китай-городе в тот день погибло шесть или семь тысяч москвитян. В лавках, называемых клетями и устроенных наподобие краковских суконных рядов, тела убитых были навалены друг на друга. Люди бежали к воротам, показывая знаками, что они ни в чем не виноваты. Я не разрешил их трогать и пропустил через свои ворота до полутора тысяч человек» [12, с. 89]. В реляции Я. Коморовского действия польско-литовского гарнизона оправдывались сопротивлением, начатым самими жителями Москвы: «измену так начали: улицы все бревнами забросали, бочками, санями, досками перегородили, дабы ни конные, ни пешие пройти не могли; стрелков в клетях, из коих товары самые лучшие несколькими днями ранее повывозили, с рушницами, копьями да рогатинами засадили» [4, c. 295]. В ответ началось ожесточенное наступление на укрепления, находившиеся под контролем польско-литовского гарнизона.

На переговорах с польско-литовскими послами 1615 г. московская сторона обвиняла А. Госевского в начатой им войне против мирных и безоружных людей: «а торговых людей секли, заперши в Китай город, в четвертом да в пятом часу дни, как все люди в торг сошлись, и лавки отперли и сели. А московским всяким людем и битца было им нечем, не токмо сабли или сомопалы, и ножа на бедре, и старому и немношному костыля было не сметь носить». Госевский, напротив, пытался представить свои действия как ответ на сборы сторонников П.П. Ляпунова: «а в московских людях в поспольству учала быть смута, и на польских и на литовских людей и на них бояр ненавесть болши прежнего и хотели над полскими и над литовскими людми и над ними бояры учинити измену, учали в Болшом в Каменном и в Деревяном городе збиратца многие люди со всяким боем и в колокола бить почасту» [14, л. 197 об.-198, 201-201 об.].

Первые вооруженные столкновения «черных людей и стрельцов» с силами польско-литовского гарнизона во многом были вызваны необходимостью самообороны. В боях около своего двора на Сретенке был ранен кн. Д.М. Пожарский (Л.М. Сухотин писал о «непричастности» кн. Д.М. Пожарского к делу ополчения) [20, с. 342-346]. Кроме кн. Пожарского, как свидетельствовал «Но- вый летописец», у Яузских ворот «на Кулишках» бился И.М. Бутурлин, а за Москвой-рекой - И. Колтовский. Впрочем, по предположению Ю.М. Эскина, в этот момент вожди дворянской части земского движения, включая кн. Д.М. Пожарского, возможно, «попытались упредить события и установить контроль над городом до прихода основных сил Ополчения» $[23$, с. $51-52,338]$. Бои оказались безуспешными, хотя они и свидетельствовали о прямой поддержке земского движения населением столицы. Для А. Госевского начавшаяся война стала предлогом для уничтожения московского посада, сожженного по его приказу до подхода основных отрядов Первого ополчения [5, ст. 229-230; 6, с. 64]. Одновременно расправились с недовольными действиями короля Сигизмунда III членами Боярской думы. Погиб находившийся под арестом боярин кн. А.В. Голицын, были убиты думный дворянин И.М. Пушкин, кн. А.М. Лобанов-Ростовский, «и иных многих княжат и боярских детей великих родов оплоша многих побили» (в суматохе бежал от приставов В.И. Бутурлин) [14, л. 201; 4, с. 295].

Новые изменения произошли в положении патриарха Гермогена. Он оставался во главе «освященного собора», и к нему по-прежнему обращались с официальными посланиями из-под Смоленска (например, при отсылке посольства А. Жолкевского 29 марта 1611 г.) $[17$, с. 264], но после московского восстания его перевели с патриаршего двора на подворье Кирилло-Белозерского монастыря в Кремле [3, с. 625-626]. Вспоминая об этом на переговорах 1615 г., польско-литовские дипломаты снова обвиняли патриарха Гермогена в призыве ополчения к Москве: «што смута всчалася и кровь хрестианская пролилася от него, и из городов люди пришли и городы отложилися по его ж зсылке: што есьмо вам письмом показали, да и сами ведаете то подлинно» [1, № 209, с. 486]. Волнения в Москве утихли только в Великий четверг - 21 марта, когда началась повторная присяга на имя королевича Владислава, а остававшихся в столице людей, в знак покорности, обязали перепоясываться «рушниками». Однако уже на следующий день стало известно о подходе к Москве одного из отрядов Первого ополчения во главе с А. Просовецким [4, с. 282-285]. 
С военной точки зрения уничтожение посадов и стрелецкой слободы в Замоскворечье означало подготовку к осаде столицы. Иноземный гарнизон, затворившийся в московских укреплениях, получал ощутимое преимущество, так как подходившие к столице ополченцы лишались необходимого им крова и продуктов. Ротмистр Н. Мархоцкий вспоминал в «Истории Московской войны»: «Деревянные стены выгорели дотла, люди уходили из города в окрестные слободы и монастыри. Был оставлен и Белый город: все люди ушли в поле, так что наши, не встретив сопротивления, выжгли и его до основания. Этот пожар все разорил, погубил великое множество людей. Великие и неоценимые потери понесла в тот час Москва» $[12$, с. $90-91]$.

Московский пожар 19 марта и подавление первых выступлений стали рубежом, после которого были уже невозможны прежние договоренности с представителями короля Сигизмунда III о династическом союзе с Речью Посполитой. В новой крестоцеловальной записи участников движения по созданию Первого ополчения полностью отказывались от поддержки кандидатур короля Сигизмунда III и королевича Владислава: «королю и королевичу полскому и литовскому креста не целовати, и не служити и не прямити ни в чем никоторыми делы» [2, № 188 , с. $319-320 ; 8$, с. $31 ; 17$, c. 262-263]. Трагедия Москвы названа в источниках «конечным разорением». Она мобилизовала людей на отпор врагу, что с особой силой было выражено в «Новой повести о преславном Российском царстве». Ее безымянный автор обращался с призывом к своим современникам: «Что стали, что оплошали? Чего ожидаете и врагов своих на себя попущаете...». Он звал всех к «делу-подвигу» спасения Москвы: «Время, время пришло» [13, с. 170, 172].

Результаты. Таким образом, главный представитель короля Сигизмунда III в Москве А. Госевский предпринимал целенаправленные усилия по противодействию сбору сил земского ополчения во главе с рязанским воеводой Прокофием Ляпуновым. Он ослабил стрелецкие отряды в составе московского гарнизона, разоружил посадских людей. Когда были получены первые известия о готовившемся в уездах походе на Москву, А. Госевский стал координировать свои действия с королевской ставкой, и пытался организовать коалицию с гетманом самозванца Яном Петром Сапегой (впрочем, неудачно, все, что ему удалось добиться на том этапе - нейтралитета сапежинского «товарищества»). Верно были выбраны направления действий, связанные с перекрытием основных дорог, по которым ополчение могло двигаться к Москве. Однако известный поход под Владимир рати боярина кн. И.С. Куракина оказался неудачным, и ему не удалось остановить земское объединение, хотя и затруднило организацию движения в близлежащих городах. Участие в этом походе принимали также польские роты, что отчасти повторяло конфигурацию действий русских воевод под присмотром «панов», как в тушинские времена. Заметной в это время была и роль отрядов «черкас» запорожских казаков, совершивших, как выясняется из неизвестного продолжения «Дневника королевского похода под Смоленск» и других источников, карательный поход в «украинные города» (Орел, Кромы, Карачев и Болхов). Эти сведения объясняют отсутствие в Первом ополчении отдельных ратных отрядов из этой части Московского государства.

Главный военный удар был нанесен в Москве 19 марта 1611 г., что привело к восстанию жителей московского посада, поддержанному сторонниками Первого ополчения, оказавшимися в этот момент в Москве. Даже его непосредственный повод - отказ от участия в работах по размещению пушек на стенах Кремля и Китай-города - показывает подготовку к осаде столицы. А. Госевский не скрывал на переговорах с русской стороной в 1615 г., что действовал превентивно, усмиряя начавшийся бунт московских посадских людей. Следствием этих событий стало уничтожение укреплений московского посада и гибель многих служилых и посадских людей, означавшие настоящее начало освободительной войны в России.

\section{ПРИМЕЧАНИЕ}

${ }^{1}$ Статья подготовлена в рамках проекта Института российской истории РАН по написанию многотомного академического труда «История России с древнейших времен до наших дней». Публикуется в целях апробации. 
The article was prepared within the project of the Institute of Russian History of the Russian Academy of Sciences on writing "History of Russia from ancient times to our days" multi-volume academic work. Published for testing purposes.

\section{СПИСОК ЛИТЕРАТУРЫ}

1. Акты, относящиеся к истории Западной России, собранные и изданные Археографической Комиссией. - СПб. : Тип. Эдуарда Праца, 1851. T. $4: 1588-1632 .-584$ c.

2. Акты, собранные в библиотеках и архивах Российской империи Археографической экспедицией имп. Академии наук. - СПб. : Тип. II Отд-ния Собственной Его Императорского Величества Канцелярии, 1836. - Т. 2. -413 с.

3. Белокуров, С. А. О месте заключения патриарха Гермогена в 1611-1612 гг. / С. А. Белокуров // Сборник статей в честь Матвея Кузьмича Любавского. - Пг. ; [Тип. Б. Д. Брукера], 1917. - С. 621-626.

4. Бохун, Т. Пацификация и пожар Москвы 29 марта - 5 апреля 1611 года / Т. Бохун // Мининские чтения : сб. науч. тр. по истории Смутного времени в России начала XVII в. В память 400-летия Нижегородского Подвига. - Н. Новгород : Нижегород. гос. ун-т им. Н.И. Лобачевского. - 2012. - С. 280-303.

5. Будило Иосиф. Дневник событий, относящихся к Смутному времени (1603-1613 гг.), известный под именем истории ложного Димитрия // Русская историческая библиотека, издаваемая Археографической комиссией. - СПб. : Печатня В.И. Головина, 1872. - Т. 1. - Ст. 81-364.

6. Дневник Маскевича. 1594-1621 // Сказания современников о Димитрии Самозванце / [с предисл. Н. Г. Устрялова]. - Изд. 3-е, испр. - СПб. : Тип. Император. акад. наук, 1859. - Ч. 2. - С. 7-124.

7. Дневник Яна Петра Сапеги (1608-1611) / сост. И. О. Тюменцев, М. Яницкий, Н. А. Тупикова, А. Б. Плотников ; под ред. И. Грали, И. О. Тюменцева. - М. ; Варшава : Древлехранилище, - 2012. (Памятники истории Восточной Европы. Источники XV-XVII вв. T. IX). -455 с.

8. Долинин, Н. П. Подмосковные полки (казацкие «таборы») в национальном движении 16111612 гг. / Н. П. Долинин. - Харьков : Изд-во Харьков. гос. ун-та им. А.М. Горького, 1958. - 130 с.

9. Кабанов, А. Ю. Казачий атаман Андрей Захарович Просовецкий - один из организаторов Первого ополчения / А. Ю. Кабанов // Смутное время и земские ополчения в начале XVII века. К 400-летию создания Первого ополчения под предводительством П. П. Ляпунова : сб. тр. Всерос. науч. конф., г. Рязань, 11-12 апр. 2011 г. - Рязань : Рязан. ист.архит. музей-заповедник, 2011. -С. 143-149.
10. Козляков, В. Н. «Дневник похода короля Сигизмунда III под Смоленск» как источник по истории Первого ополчения / В. Н. Козляков // Вспомогательные исторические дисциплины в современном научном знании : материалы XXXII Междунар. науч. конф., г. Москва, 11-12 апр. 2019 года. М. : Изд-во Рос. гос. гуманит. ун-та, 2019. - С. 203-206.

11. Костомаров, Н. И. Собрание сочинений / Н. И. Костомаров. - СПб. : О-во для пособия нуждающимся литераторам и ученым («Лит. фонд»), 1904. - Кн. 2. - Т. 4-6. Смутное время Московского государства в начале XVII столетия. -672 с.

12. Мархоцкий, Н. История Московской войны / Н. Мархоцкий ; подгот. публ., пер., ввод. ст., коммент. Е. Куксиной. - М. : РОССПЭН, 2000. $222 \mathrm{c}$.

13. Новая повесть о преславном Российском царстве // Библиотека литературы Древней Руси. T. 14. Конец XVI - начало XVII века. - СПб. : Наука, 2006. $-758 \mathrm{c}$.

14. Посольская книга по связям России и Польши 1615-1616 гг. // Российский государственный архив древних актов. -Ф. 79 : Сношения России с Польшей. - Оп. 1. - Д. 30. - 1054 л.

15. Рабинович, Я. Н. Малые города Новгородской земли в Смутное время / Я. Н. Рабинович. Великий Новгород : Изд-во НовГУ им. Ярослава Мудрого, 2013. - 433 с.

16. Русский архив Яна Сапеги 1608-1611 годов. Тексты, переводы, комментарии / под ред. И. О. Тюменцева. - Волгоград : Изд-во Волгогр. фил. РАНХиГС, 2012. $-687 \mathrm{c}$.

17. Сборник имп. Русского исторического общества. - СПб. : Тип. Г. Лисснера и Д. Собко, 18671916. - 148 т. - 1913. - Т. 142. - 804 с.

18. Собрание государственных грамот и договоров, хранящихся в Государственной коллегии иностранных дел. - М. : Тип. Селивановского, 1819. Ч. $2 .-610 \mathrm{c}$.

19. Селин, А. А. Новгородское общество в эпоху Смуты / А. А. Селин. - СПб. : Изд-во «РусскоБалтийский информационный центр “БЛИЦ”", 2008. -752 c.

20. Сухотин, Л. М. К вопросу о причастности патриарха Гермогена и князя Пожарского к делу первого ополчения / Л. М. Сухотин // Сборник статей в честь Матвея Кузьмича Любавского. - Пг. : [Тип. Б. Д. Брукера], 1917. - С. 318-346.

21. Флоря, Б. Н. Польско-литовская интервенция в России и русское общество / Б. Н. Флоря. М. : Индрик, 2005. -415 с.

22. Эйльбарт, Н. В. Смутное время в польских документах Государственного архива Швеции. Комментированный перевод и исторический анализ / Н. В. Эйльбарт. - Новосибирск : Изд-во Сибир. отд-ния Рос. акад. наук, 2013. - 399 с. 
23. Эскин, Ю. М. Дмитрий Михайлович Пожарский / Ю. М. Эскин. - М. : Квадрига, 2018. $379 \mathrm{c}$.

24. Diariusz drogi króla polskiego Zygmunta III od szczęśliwego wyjazdu z Wilna pod Smoleńsk w roku 1609 a die 18 Augusti i fortunnego powodzenia [...] do wziźcia zamku Smoleńska w roku 1611. Riksarkivet. Skoklostersamlingen. E8597. P. 308-372 rev. Electronic text data. - Mode of access: http://repcyfr. $\mathrm{pl} /$ dlibra/doccontent?id=207\&from=\&dirids $=1 \& \mathrm{ver}$ $\mathrm{id}=221 \& \mathrm{lp}=155 \& \mathrm{QI}=$ !91C388AC14EB18F5AF864C 9FF3399475-3 (date of access: 05.06.2020). - Title from screen.

\section{REFERENCES}

1. Akty, otnosyashchiyesya $k$ istorii Zapadnoy Rossii, sobrannyye i izdannyye Arkheograficheskoy Komissiyey [Acts Related to the History of Western Russia, Collected and Published by the Archaeographic Commission]. Saint Petersburg, Tipografiya Eduarda Pratsa, 1851, vol. 4: 1588-1632. 584 p.

2. Akty, sobrannyye $v$ bibliotekakh i arkhivakh Rossiyskoy imperii Arkheograficheskoy ekspeditsiyey imp. Akademii nauk [Acts Collected in the Libraries and Archives of the Russian Empire by the Archaeographic Expedition of Imperial Academy of Sciences]. Saint Petersburg, Tipografiya II otdeleniya Sobstvennoy Ego Imperatorskogo Velichestva Kantselyarii, 1836, vol. 2. 413 p.

3. Belokurov S.A. O meste zaklyucheniya patriarkha Germogena v 1611-1612 gg. [On the Place of Imprisonment of the Patriarch Germogen in 16111612]. Sbornik statey $v$ chest' Matveya Kuz'micha Lyubavskogo [Collection of Articles in Honor of Matvey Kuzmich Lubavsky]. Petrograd, Tipografiya B.D. Brukera, 1917, pp. 621-626.

4. Bohun T. Patsifikatsiya i pozhar Moskvy 29 marta -5 aprelya 1611 goda [Pacification and Fire of Moscow March 29 - April 5, 1611]. Mininskiye chteniya: sb. nauch. tr. po istorii Smutnogo vremeni $v$ Rossii nachala XVII v. V pamyat'400-letiya Nizhegorodskogo Podviga [Minin Readings: Collection of Scientific Works on the History of the Time of Troubles in Russia at the Beginning of the $17^{\text {th }}$ Century. In Memory of the $400^{\text {th }}$ Anniversary of the Nizhny Novgorod Zemstvo Militia]. Nizhny Novgorod, Nizhegorodskiy gosudarstvennyy universitet im. N.I. Lobachevskogo, 2012, pp. 280-303.

5. Budilo Joseph. Dnevnik sobytiy, otnosyashchikhsya k Smutnomu vremeni (16031613 gg.), izvestnyy pod imenem istorii lozhnogo Dimitriya [A Diary of Events Related to the Time of Troubles (1603-1613), Known as the History of False Demetrius]. Russkaya istoricheskaya biblioteka, izdavayemaya Arkheograficheskoy komissiyey [Russian Historical Library, Published by the Archaeographic Commission]. Saint Petersburg, Pechatnya V.I. Golovina, 1872, vol. 1, pp. 81-364.

6. Dnevnik Maskevicha. 1594-1621 [Diary of Maskevich. 1594-1621]. Ustryalov N.G., ed. Skazaniya sovremennikov o Dimitrii Samozvantse [Tales of Contemporaries About Demetrius the Imposter]. $3^{\text {rd }}$ edition. Saint Petersburg, Tipografiya Imperatorskoy Akademii Nauk, 1859, pt. 2, pp. 7-124.

7. Tyumentsev I.O., Yanitsky M., Tupikova N.A., Plotnikov A.B., comp., Grali I., Tyumentsev I.O., eds. Dnevnik Yana Petra Sapegi (1608-1611) [Diary of Jan Peter Sapieha (1608-1611)]. Moscow, Warsaw, Drevlekhranilishche Publ., 2012. (Pamjatniki istorii Vostochnoj Evropy. Istochniki XV-XVII vv. Centuries. T. IX [Monuments of the History of Eastern Europe. Sources of the XV - XVII Centuries. Vol. IX.). 455 p.

8. Dolinin N.P. Podmoskovnye polki (kazackie «tabory») v nacional'nom dvizhenii 1611-1612 gg. [Regiments Near Moscow (Cossack "Camps") in the National Movement of 1611-1612]. Kharkiv, Izd-vo Kharkovskogo gosudarstvennogo universiteta im. A.M. Gorkogo, 1958. 130 p.

9. Kabanov A.Yu. Kazachiy ataman Andrey Zakharovich Prosovetskiy - odin iz organizatorov Pervogo opolcheniya [Kazachiy Ataman Andrei Zakharovich Prosovetsky - One of the Organizers of the First Militia]. Smutnoye vremya $i$ zemskiye opolcheniya $v$ nachale XVII veka. K 400-letiyu sozdaniya Pervogo opolcheniya pod predvoditel'stvom P.P. Lyapunova: sb. tr. Vseros. nauch. konf., g. Rjazan', 11-12 apr. $2011 \mathrm{~g}$. [Time of Troubles and Zemstvo Militias at the Beginning of the $17^{\text {th }}$ Century. On the $400^{\text {th }}$ Anniversary of the First Militia, Led by P.P. Lyapunov. Proceedings of the All-Russian Scientific Conference. Rjazan', April 11-12, 2011]. Ryazan, Ryazanskiy istoriko-arkhitekturnyy muzeyzapovednik, 2011, pp. 143-149.

10. Kozlyakov V.N. «Dnevnik pokhoda korolya Sigizmunda III pod Smolensk» kak istochnik po istorii Pervogo opolcheniya ["Diary of the Campaign of King Sigismund III Near Smolensk" as a Source on the History of the First Militia]. Vspomogatel'nyye istoricheskiye distsipliny $v$ sovremennom nauchnom znanii: materialy XXXII Mezhdunar. nauch. konf., g. Moskva, 11-12 apr. 2019 goda [Auxiliary Historical Disciplines in Modern Scientific Knowledge. Materials of the XXXII International Scientific Conference. Moscow, April 11-12, 2019]. Moscow, Izd-vo Rossiyskogo gosudarstvennogo gumanitarnogo universiteta, 2019, pp. 203-206.

11. Kostomarov N.I. Sobraniye sochineniy [Collected Works]. Saint Petersburg, O-vo dlya posobiya nuzhdayushchimsya literatoram i uchenym («Lit. fond»), 1904, book 2, vol. 4-6. Smutnoye vremya 


\section{ВООРУЖЕННЫЕ СИЛЫ И ВОЕННЫЕ ДЕЙСТВИЯ}

Moskovskogo gosudarstva v nachale XVII stoletiya [The Time of Troubles of the Moscow State at the Beginning of the $17^{\text {th }}$ Century]. $672 \mathrm{p}$.

12. Marhotsky N., Kuksina Ye., eds. Istoriya Moskovskoy voyny [History of the Moscow War]. Moscow, ROSSPEN Publ., 2000. 222 p.

13. Novaya povest' o preslavnom Rossiyskom tsarstve [A New Story About the Glorious Russian Kingdom]. Biblioteka literatury Drevney Rusi. T. 14. Konets XVI-nachalo XVII veka [Library of Literature of Ancient Russia. Vol. 14. The End of the XVI - the Beginning of the XVII Century]. Saint Petersburg, Nauka Publ., 2006. 758 p.

14. Posol'skaya kniga po svyazyam Rossii i Pol'shi 1615-1616 gg. [The Ambassadorial Book on the Relations of Russia and Poland 1615-1616]. Rossijskij gosudarstvennyj arhiv drevnih aktov [Russian State Archive of Ancient Acts], f. 79: Snosheniya Rossii s Polshey [Relations of Russia with Poland], inv. 1, d. 30, 10541.

15. Rabinovich Ya.N. Malyye goroda Novgorodskoy zemli $v$ Smutnoye vremya [Small Towns of Novgorod Land in the Time of Troubles]. Veliky Novgorod, Izd-vo NovGU im. Yaroslava Mudrogo, 2013. 433 p.

16. Tyumentsev I.O., ed. Russkiy arkhiv Yana Sapegi 1608-1611 godov. Teksty, perevody, kommentarii [The Russian Archive of Jan Sapieha 1608-1611. Texts, Translations, Comments]. Volgograd, Izd-vo Volgogradskogo filiala RANKhiGS, 2012. 687 p.

17. Sbornik imp. Russkogo istoricheskogo obshchestva [Collection of Imperial Russian Historical Society]. Saint Petersburg, Tipografiya G. Lissnera i D. Sobko, 1867-1916. 148 vols. 1913, vol. 142.804 p.

18. Sobraniye gosudarstvennykh gramot $i$ dogovorov, khranyashchikhsya v Gosudarstvennoy kollegii inostrannykh del [A Collection of State Letters and Treaties Held by the State College of
Foreign Affairs]. Moscow, Tipografiya Selivanovskogo, 1819, pt. 2. 610 p.

19. Selin A.A. Novgorodskoye obshchestvo v epokhu Smuty [Novgorod Society in the Time of Troubles]. Saint Petersburg, Izd-vo «Russko-Baltiyskiy informatsionnyy tsentr "BLITs"», 2008. 752 p.

20. Sukhotin L.M. K voprosu o prichastnosti patriarkha Germogena i knyazya Pozharskogo k delu pervogo opolcheniya [On the Issue of the Involvement of Patriarch Germogen and Prince Pozharsky in the Case of the First Militia]. Sbornik statey $v$ chest' Matveya Kuz'micha Lyubavskogo [Collection of Articles in Honor of Matvey Kuzmich Lyubavsky]. Petrograd, Tipografiya B.D. Brukera, 1917, pp. 318-346.

21. Florya B.N. Pol'sko-litovskaya interventsiya $v$ Rossii i russkoye obshchestvo [Polish-Lithuanian Intervention in Russia and Russian Society]. Moscow, Indrik Publ., 2005. 415 p.

22. Eilbart N.V. Smutnoye vremya v pol'skikh dokumentakh Gosudarstvennogo arkhiva Shvetsii. Kommentirovannyy perevod i istoricheskiy analiz [The Time of Troubles in the Polish Documents of the State Archive of Sweden. Commented Translation and Historical Analysis]. Novosibirsk, Izd-vo Sibirskogo otdeleniya Rossiyskoy akademii nauk, 2013. 399 p.

23. Eskin Yu.M. Dmitriy Mikhaylovich Pozharskiy [Dmitry Pozharsky]. Moscow, Kvadriga Publ., 2018. 379 p.

24. Diariusz drogi króla polskiego Zygmunta III od szczę́liwego wyjazdu z Wilna pod Smoleńsk w roku 1609 a die 18 Augusti i fortunnego powodzenia [...] do wziźcia zamku Smoleńska w roku 1611 [The Diary of the Campaign of King Sigismund III Near Smolensk in 1609-1611]. Riksarkivet. Skoklostersamlingen. E8597, pp. 308-372 rev. URL: http://repcyfr.pl/dlibra/ doccontent?id $=207 \&$ from $=\&$ dirids $=1 \&$ ver $\mathrm{id}=221 \& 1 \mathrm{p}=$ 155\&QI=!91C388AC14EB18F5AF864C9FF3399475-3 (accessed 5 June 2020).

\section{Information About the Author}

Vyacheslav N. Kozlyakov, Doctor of Sciences (History), Professor, Department of Russian History, Ryazan State University named after S.A. Esenin, Svobody St, 46, 390000 Ryazan, Russian Federation, v.kozliakov@365.rsu.edu.ru,https://orcid.org/0000-0003-2840-9767

\section{Информация об авторе}

Вячеслав Николаевич Козляков, доктор исторических наук, профессор кафедры истории России, Рязанский государственный университет им. С.А. Есенина, ул. Свободы, 46, 390000 г. Рязань, Российская Федерация, v.kozliakov@365.rsu.edu.ru, https://orcid.org/0000-0003-2840-9767 